\title{
RECONNECTING THE PHILOSOPHY OF RELIGION AND ENGAGED RELIGIOUS REASONING
}

\author{
FRANCIS X. CLOONEY, SJ
}

Harvard University

\begin{abstract}
It is no surprise that the philosophy of religion, the many disciplines counted within the study of religion and theology, and religion-specific studies, all have their own methods and interests, and often proceed necessarily as conversations among small groups of experts. But the intellectual cogency and credibility of such studies also entails a problematization of the boundaries that divide them. While disciplinary distinctions are necessary and valuable, a freer flow of ideas and questions across boundaries is to the benefit of all concerned. In particular, the philosophy of religion proceeds more fruitfully if, among its several dimensions, it is also intentionally comparative and interreligious, vulnerable to the questions raised by insiders to traditions, and open to the implications of ideas for religious practice.
\end{abstract}

I have never counted myself among those expert in the philosophy of religion, instead locating myself among those theologians who seek to understand their faith by detailed and rigorous study of the ideas and arguments presented in a religious tradition other than their own. Yet the comparative work I am interested in repeatedly places before me the philosophical and religious arguments of pre-modern Hindu intellectuals who often enough do not neatly separate philosophical and theological reasoning. And so I do turn occasionally to the state of the question regarding the philosophy of religion as a philosophical and religious discipline, with homes in both academe and amidst religious communities.

It was therefore with great interest that I recently read William Wood's essay, "On the New Analytic Theology, or: The Road Less Traveled." In it

${ }^{1}$ Journal of the American Academy of Religion (December 2009), Vol. 77, No. 4, pp. 941-960. 
he reviews several notable new volumes in the field of analytic philosophy of religion and related theological disciplines. ${ }^{2}$ Wood also estimates the state of the fields wherein philosophy, theology, and the study of religion intersect; early on, he characterizes in this way the current standoff among philosophers, theologians, and scholars of religion:

Most scholars working in the religious studies academy have little use for analytic philosophy. They tend to treat it with suspicion when they consider it at all, which is rarely. For their part, most analytic philosophers of religion return the favor by ignoring contemporary theology and continental philosophy of religion, to say nothing of the other subdisciplines of religious studies. Many practitioners of religious studies believe that analytic philosophy of religion is merely a stalking horse for oppressive and antiquated forms of traditional Christianity. Conversely, analytic philosophers of religion often treat practitioners of religious studies as silly, unserious, uninterested in truth, and unwilling if not unable to appreciate that the rational case for traditional Christianity is actually quite strong. (942)

Lack of communication depends on justificatory caricatures, and on narrow professional boundaries that encourage and reify the exclusion of other disciplines. But Wood also sees the irony in the fact that constructive religious reflection flourishes quite apart from ordinary, seemingly wayward theological reflection:

From a certain point of view, the entire situation is bizarre. On the one hand, what can only be called constructive theology, and of a very traditional sort, is currently flourishing in philosophy departments, in near total isolation from the actual academic discipline of theology. On the other hand, the actual academic discipline of theology remains fractured and embattled, under attack from all sides, unsure of its place not only in the academy, but in churches and divinity schools as well. (942-3)

${ }^{2}$ Including: A Reader in Contemporary Philosophical Theology, edited by Oliver D. Crisp. New York: Continuum, 2009; Analytic Theology: New Essays in the Philosophy of Theology, edited by Oliver D. Crisp and Michael C. Rea, New York: Oxford University Press, 2009; The Oxford Handbook of Philosophical Theology, edited by Thomas P. Flint and Michael C. Rea, New York: Oxford University Press, 2009; Oxford Readings in Philosophical Theology, Vol. 1: Trinity, Incarnation, Atonement, and Vol. 2: Providence, Scripture, and Resurrection, both edited by Michael C. Rea. New York: Oxford University Press, 2009. 
Near the end of the essay, Wood reminds us that we cannot take for granted as if settled any particular narrative regarding how reasoning stands in relationship to the goals of academic scholarship and religious reflection:

[S]cholars who advocate a sharp distinction between theology and the study of religion find themselves defending, if not quite disengaged reason, at least the scientific status of all genuine academic work in religious studies. That is, whether they accept or reject various claims about postmodernity, opponents of postmodern theology continue to criticize it for failing to live up to the proper canons of rational inquiry in the academy. But down the hall from the department of religion, we find another discipline, philosophy, with sterling academic credentials and its own methodological norms, norms that do seem to legitimate exactly the practice that our own opponents of theology will not countenance-namely, the practice of making and assessing truth claims about God. (958)

Religion departments may be undercutting the credibility of religious beliefs, as if for the sake of autonomous judgments on religion, while the rigorous analysis of religious claims in philosophy departments may conversely make available persuasive defenses of religious beliefs.

Wood's estimate of the situation is of course open to discussion and further nuance, but overall it rings true. More work needs to be done to remedy the stubbornly enduring and unproductive separation between philosophical discourse and intellectual reflection within religious traditions and among practitioners, that we might get clearer about the relationship between reasoning about religious topics and the engaged religious reasoning practiced within the bounds of a faith perspective.

From the vantage point of comparative theology, ${ }^{3}$ I suggest that we need also to break down the artificial boundary between reasoning about and from religious perspectives in the (Christian) West, and the similar forms of reasoning quite evident in other religious traditions. We still act as if geographical borders and specific histories excuse us from including in our conversations potential interlocutors in other traditions. The relation between the philosophy of religion and theology, between

${ }^{3}$ See Francis X. Clooney, SJ, Comparative Theology: Deep Learning across Religious Borders (Wiley-Blackwell, 2010). 
such intellectual disciplines and religious practice as motivating and contextualizing thinking, and between Western Christian intellectual practices and those found elsewhere in the world, are more effectively tackled when addressed together.

To offer a modest contribution to the larger ongoing conversation, as the core of this essay I reflect on yet another recent publication, Parimal Patil's Against a Hindu God: Buddhist Philosophers of Religion in India, and from there trace a path of widening religious reflection. In this 2009 monograph, Patil aims first of all to get straight the Buddhist philosopher Ratnakirti's critique of Hindu logicians' arguments in favor of the existence of a creator god. Against the background of a general exposition of the epistemological framework of the argument about a world-maker - taken to be divine, i.e. God (Chapter 2), Patil explores Ratnakirti's understanding of relation and pervasion (Chapter 3), key elements in the arguments on both the Buddhist and Hindu sides. $\mathrm{He}$ then considers the relevant Buddhist epistemology, particularly the logically and rhetorically important concept of "exclusion" (Chapter 4), and finally the structure of Ratnakirti's Buddhist worldview as a whole, as implicit in the arguments (Chapter 5).

This is not an easy book, nor could it be. Even a reader already somewhat familiar with Indian dialectics must be ready for a heavy dose of technical detail and refined terminology. Although Patil strives for clarity, the arguments, rigorous and concisely delineated, remain daunting; but the technicalities serve clarity in argument and regarding the goals of argument, which otherwise lose cogency. ${ }^{4}$

Although the book deals primarily with "the philosophical content of an interreligious debate between Buddhist and Hindu intellectuals in premodern India," as argued by Ratnakirti, Patil is also interested in "moving beyond the usually historical and philological task of restating, in English, complex arguments formulated in Sanskrit." (4) The demonstration that there is a broader intellectual accessibility such as commands our attention across cultural and religious boundaries is in fact key to Patil's overall project. He wants to build bridges, so as to

${ }^{4}$ For example, the book is replete with coded abbreviations, e.g., C1, performance conditions; C2, instrument conditions/triple conditions; C3 argument conditions - and these as nuanced by a series of " $\mathrm{H}$ " distinctions: $\mathrm{H1a}$, "unestablished in the site of inference", H1b, "opposed," that is, a "direct defeater," and all the way to H5, "too late." 
enable interested and willing philosophers, particularly in the Western academy, to engage more substantively in reflection on the arguments posed by Ratnakirti and his interlocutors. Patil offers substantive analyses of such arguments in a conceptual framework that recognizes both indigenous Indian, and Western, modes of religious/philosophical argumentation. In this way, Patil is emphasizing the value of "thinking (in) Sanskrit," even for readers who do not know the Sanskrit language and have not thoroughly mastered the technical terminology of Indian logic. Any of us, he suggests, can learn enough so as to begin to have in place ways of thinking about religious and philosophical issues that are indebted to India and not merely Western traditions applied to Hindu and Buddhist arguments.

To ground this mix of detail and epistemological reconsideration, Against a Hindu God models a transdisciplinary learning that draws on three sources - South Asian studies, philosophy, and study of religion. By means of this learning, Patil hopes to rethink the boundaries among these disciplines for the sake of a "new kind of philosophy of religions." (6) Much of it has to do with a willingness to read, with care and patience. Patil scolds scholars of South Asian studies for infatuation with "the social, cultural, and political 'outsides' of texts." Given the avid turn to contextual issues, it may seem as if texts are interesting primarily because of what can be wrested from them regarding context, insights into social, political and power concerns that, while relevant to interpretation, are simply not what the texts say and are about. He traces this attitude to "the tyranny of social and cultural history, and a closely related distrust of philosophy." (6) Endemic too is a predilection for academic theories generated outside of India and then merely applied to Indian texts, as if such texts are meant to provide data by which to test Western theories about Hindus, Buddhists and their arguments. As Patil rightly reports, specific arguments from the Indian context, such as Ratnakirti and the Hindu logicians trade back and forth, do more than tell us something about social conditions and power constructions in premodern South Asia. They get us to think often more rigorously and certainly differently, about issues of wide import and subject to debate in the West. For example: can it be shown that God exists?

Patil robustly argues that the Indian debates, when taken seriously on internal grounds - in terms of what the texts say - are philosophically 
interesting, and for that reason, remain pertinent centuries later. Indeed, they form "an intellectually available source from which wecan learn today" regarding "the nature of rationality, the metaphysics of epistemology, and the relevance of philosophy to the practice of religion." (4)

Stepping back from the details, Patil highlights four benefits of the approach he is defending. First, "focused attention on the philosophical content and significance of Ratnakirti's arguments will remind historians of religion of the importance of intellectual contexts to the study of religion." And, I might clarify, not only the social contexts of texts matter, but also internal contexts, ideas. Second, philosophers of religion will be enabled to see the relevance of these Indian materials to their field, and to move beyond an overly Christian-based set of "Christian texts and textual traditions." (13) Third, the book will enable diligent and open-minded philosophers to begin to philosophize using Sanskrit materials often abandoned as accessible only to the specialist. Fourth, all of this will make evident that what is learned in South Asian studies, including philosophy, is of relevance to a much wider audience than those interested in India and South Asia. Ratnakirti and his interlocutors are philosophers, and of interest to the wider philosophical audience. $(13-14)^{5}$

If all this adds up to an ambitious agenda, Patil is also interested in a still deeper and more robust defense of this philosophical argumentation as religiously informative. At the end of the volume he makes the interesting move of uncovering the pedagogical and religious dimensions of the Buddhist argumentation he has been studying. According to Jnanasrimitra

\footnotetext{
${ }^{5}$ Along the way, Patil also insists on a fresh approach to the comparative dimension of comparative philosophy. The project of studying Ratnakirti with these sensitivities and expectations is comparative because it brings together "two or more components that are generally taken to be different" - from different entities or "patients," or "different features of a single, multivalent component, or both." (22) Whenever an entity is studied in this expansive way, the study becomes a comparative one. It allows for "narrow" comparisons (dealing with historically related entities) and "broad" comparisons (which bring hitherto unrelated elements into a single reflection). The model also allows for a very rich variety of exempla, since many different kinds of entities can be compared, including processes. (23) While this notion of comparison seems too broad - and liable to the uninteresting generalization that all learning is comparative - it neatly escapes any standard "Western-other" dichotomy, and so makes it at least seem noncontroversial that the preoccupations of the West regarding its own uniqueness are no longer interesting.
} 
(Ratnakirti's teacher), advancement in proper argumentation is as it were the ascent of a ladder of ideas and insights, rising toward superior, fuller viewpoints; "the way that one learns to move up from rung to rung of this ladder is by discovering conceptual problems inherent in how we speak about awareness and its objects." (350) Philosophy by this account "is of pedagogical significance, since it is through philosophical analysis and argumentation that a teacher like Jnanasrimitra is able to help his 'students' move up from rung to rung of a philosophical stepladder... [P] hilosophy is supposed to change people's minds by turning them away from their false or partially true views and toward those that are more correct." (350)

Buddhist argument with the Hindu logicians thus offers valuable training in philosophy, but not only for the sake of establishing correct philosophical views; rather, in accord with Buddhist insight, the end result is also the defense of the correctness of the selflessness-momentariness thesis, by which "Ratnakirti further identifies selflessness and the thesis that all existing things are momentary as the unique teachings of the Buddha, and thus ... that they alone are the proper objects for meditation." (331) This identification is defended on the grounds of a proper epistemology and set of arguments about the self, a world-maker, etc. And all this is in turn propaedeutic to right practice, since "meditating upon selflessness-momentariness can lead to omniscience - that is, the direct awareness of dharma itself.' (355) But this means that the technical Buddhist philosophical arguments are also relevant to our understanding of "Buddhism" as a religion, of which the selflessness-momentariness thesis is the essential, distinguishing feature. Even as Ratnakirti is uncompromising in the rigor of his philosophical arguments, the overall structure of his discourse "is determined by both philosophical and soteriological concerns that are informed by Ratnakirti's understanding of the Buddhist path." (362) Or, to put it another way: Buddhist religious beliefs are relevant to a proper understanding and assessment of Buddhist philosophy. Soteriology and epistemology inevitably imply one another, each incomplete until the other is taken into account.

When vigorous arguments change minds, the way is opened to better and more efficacious religious practice. This opening is a goal implicit in the stated arguments, and it marks the direction in which the arguments 
move for the sake of conclusions that are not only logical but also religious. So the philosophical and religious cohere:

$[\mathrm{P}]$ hilosophical activity, as a form of religious practice, improves one's epistemic position with respect to a soteriological goal, by both removing one's false views and fixing the right views in one's mind through very detailed and deliberate philosophical analysis. Built into this work is the expectation that upon entering this new epistemic position, one will display the necessary epistemic rationality and accept Ratnakirti's conclusions. On Ratnakirti's model, religious reasoning is a "hybrid virtue" that requires that one be sensitive to both instrumental and epistemic reasons. (362)

This hybridity requires that we get right the intellectual context, the complexity of the words, concepts, and models of reasoning, such as will disclose the coherence of reasoning and word, faith and practice.

Yet if this more generously imagined religious philosophy of religion is to make sense, it must also be possible to go a step farther and still more forthrightly make room for judgments on truth. Patil does not go far in this direction; we notice that in listing four benefits of his approach, he does not add a fifth benefit that would be highly significant - that the study of these arguments sheds light on whether a God (a maker god, the Hindu God, or some other) can be said to exist. While Patil is articulate in describing what Buddhist intellectuals take seriously for philosophical and religious purposes, he does not say whether all of it adds up to more light shed on the question of God. But the logic of Against a Hindu God pushes us toward taking very seriously the question whether God does exist, and motivates us to say more about who that God might be.

So do Buddhist arguments against the notion of a world-making divinity make it less reasonable to believe today that God exists? Are the Hindu logicians right in making the case for the divinity whom believers address as Visnu, Siva, or by another name? And if there are good reasons for the existence of Visnu, does this count for or against the existence of the Christian God? While a large number of questions surely intrude here, my point is that the overall direction of the philosophy of religion is toward taking seriously direct questions about God, even toward answering them affirmatively. 
The second chapter of my Hindu God, Christian God", "Arguing the Existence of God: From the World to Its Maker," is the closest I come in my own writing to a reasonably full treatment of a philosophical argument about God's existence. ${ }^{7}$ I wrote this book in order to show how the great theological issues that have occupied the Christian West have serious and apt counterparts in traditional Hindu theology, ${ }^{8}$ and consequently that there is no good reason for theologians serious about such issues to restrict their attention to Western and Christian sources.

In this second chapter, I deal with the existence of God as a key topic in the philosophy of religion, addressing a version of the same debate over the existence of God that Patil treats more thoroughly in his book. Like Patil, though much more briefly, I draw on Buddhist and Hindu arguments, and I also draw some parallels to the Christian tradition of the philosophy of religion, represented in this chapter by the work of Richard Swinburne. From personal motives (as a practicing Catholic) yet also for good reasons, in the chapter I entertain the view that it is more rather than less probable that there is a God who exists and, in divine perfection and with perfectly good intent, creates the world. This view remains plausible even if, the Buddhist critique aside, we also find in both the Hindu and Christian traditions that there have been important thinkers, devout theists included, who did not believe that an adequate case for the existence of God could be made and satisfactorily defended. In this project, I took arguments about God's existence to form a necessary starting point - conceptually, if not temporally - for whatever else one might wish to say about God deeper within the specific confines of individual traditions.

Yet, although I had originally imagined that my book would have been concerned solely with the issues arising in the debates about God's existence, even in chapter two I gave space to Hindu scriptural

\footnotetext{
${ }^{6}$ Hindu God, Christian God (Oxford University Press, 2001) - to which Patil wrote a concluding response.

${ }^{7}$ See also "The Existence of God, Reason, and Revelation in Two Classical Hindu Theologies," Faith and Philosophy 16/4 (2000) 523-543.

${ }^{8}$ The four main chapters of Hindu God, Christian God (Oxford University Press, 2001): c. 2, on the existence of God, beginning with Richard Swinburne, then moving to Hindu materials; c. 3, on God's proper identity, beginning with Hans Urs von Balthasar; c. 4, on whether God can become embodied, beginning with Karl Rahner; c. 5, on whether revelation tells us definitively who God is, beginning with Karl Barth.
} 
theologians (in the Mimamsa and Vedanta traditions) who do not believe that the demonstration of God's existence can ever work perfectly, while in its imperfect form it may cause doubts that are harmful. To an extent, I share that skepticism; something more than logic and appeals to natural instances of cause and effect are required if we are to think cogently about God.

But does concern for the question of God, as a real question with real implications, require faith? We ought not to slip too casually from the land of philosophy into a world of believers. Not that this would necessarily be a bad thing, even for rigorous philosophers. While the contemporary academy has for a long time had an ambition toward an objectivity that keeps its distance from faith, its practicing communities and its authorities, the reasons for this distance no longer add up to an absolute separation. If Patil is right, then the turn to religious engagement, including faith and practice, is occurring at the heart of rigorous arguments about religion, particularly when substantive classical materials are taken seriously. The split that Wood has highlighted now seems all the more problematic, since good philosophical arguments ("from the outside") and good religious arguments ("inside") all the more obviously imply one another.

In Hindu God, Christian God I was therefore also interested in additional difficult issues that arise when more specific, positive features of religious belief become topics of intellectual relevance. In the third chapter, for example, I turned to the issue of God's proper, specific name - Siva or Narayana or the God of our Lord Jesus Christ, for example - and the very conditions under which God can be convincingly recognized by one right name. While inevitably religious, the issue is also philosophically challenging, as the philosophical arguments, already difficult enough, are further complicated by decisions about whether and how reason and experience favor one specific understanding of God and one religious practice over another.

Such arguments, Hindu or Christian, entail claims about truths that have universal import, even while remaining in other ways traditionspecific. In Chapter 3 I was therefore dealing with arguments posed by Hindu and Christian thinkers who insist that there are reasons for the specificity of divine identity announced in their faith traditions. In examining Hindu arguments about whether Visnu or Siva is the supreme 
deity properly named, I suggested that these arguments stand parallel to Hans Urs von Balthasar's arguments in favor of Jesus Christ as the sole completely full and true manifestation of God properly known. In either the Hindu context or the Christian, proponents of naming God in "just this way" know very well that reason alone will not suffice for a compelling case determinative of who God is. Yet they still made arguments, and saw that without risking this extended and more vulnerable argumentation, the mere claim that God exists would remain empty.

In the fourth and fifth chapters of Hindu God, Christian God, I dealt with still more narrow specifications, taking up arguments that this God can become incarnate (c. 4), and that God can be reliably and specially revealed in specific scriptural texts (c. 5). Each chapter by plan demands more of readers, insofar as it involves still narrower commitments to specific ways of arguing that entail still more rigorous religious and philosophical tenets. Thus, the idea of incarnation will not be accepted by Muslim or Saiva theists, and the idea that sacred texts (oral, written) afford reliable encounter with and information about God will put off other believers, and not just those who adhere to one scripture while excluding all others.

This increasingly narrowed set of interests of course raises the bar for participants, even as it leaves less comfortable space for philosophers whose sentiments, personal or professional, run against treating the particularities of specific faith traditions as of compelling intellectual relevance. This process of edging deeper into religious particularities and scriptural exegesis makes it unlikely that philosophically neutral arguments will be decisive; it also narrows the conversation to the smaller group of religious intellectuals willing to take seriously factors other than reason. In turn, attention to scripture also makes it relevant to reflect on a still wider range of learning practices that afford to religious truths a more demanding cogency. Even if Patil is right in arguing that the truth of arguments is not merely community-specific, the way to get at the larger cogency and universal meaning arises through attention to "local" detail, to those specifics on which religious traditions in the end do not yield. Yet if this line of reasoning has some force to it, the obligation goes both ways. Logical arguments about God open up properly religious topics; religious arguments are weaker if reasoned argumentation is 
left to skeptics and opponents, while believers rush too quickly to safer religious resources that have little or no force with outsiders.

Once we open the door to tradition-specific religious arguments, we can ask whether there is anything to be gained by stating that this philosophical and religious reflection is itself a mode of religious activity. I believe that there are advantages, provided we do not overdo the correlation or insist that every individual thinker must be explicitly religious. It is better to move forward cautiously; Patil's case for the relevance of arguments about God and related matters will be strengthened if we become willing to speak of certain forms at least of the philosophy of religion as religious practices that are most naturally rooted in traditions of practice, even as forms of theological or religious reasoning.

A viable starting point for this further consideration is the well known "way of spiritual exercises" proposed by Pierre Hadot. Although Patil refers to Hadot only once, in passing and with a certain hesitation (p. 362), he does helpfully refer us to Matthew Kapstein's Reason's Traces, ${ }^{9}$ wherein Kapstein, himself a distinguished scholar of Buddhism, points to close parallels between Hadot's understanding of philosophy and that of Buddhist intellectuals who care about religion and argument both. Kapstein argues that "Buddhist philosophy" is in some ways more precisely "Buddhology," "the hermeneutics of buddhahood and of the message propounded by the Buddha." (19) This Buddhology proceeds with a care for revealed teachings that does not sit well with conceptions of philosophy as autonomous; indeed, it is plausible to argue that "Buddhist philosophy has never claimed for itself the perfect autonomy of reason that is often supposed to be a hallmark of the Western traditions of rational inquiry derived ultimately from the Greeks." (19) Kapstein, like Patil, shows how the study of Buddhist thought might now be undertaken "not only for interreligious reflection on arguments and practices elaborated in the past, but in considering also our unactualized prospects ... in critical reflection on its ideals of the good in relation to our contemporary predicaments." (20) I infer that Kapstein supports the model proposed by Hadot: Buddhist (or Hindu or Christian)

${ }^{9}$ Specifically, the Introduction, pp. 3-26, in Reason's Traces: Identity and Interpretation in Indian and Tibetan Buddhist Thought (Wisdom Publications, 2002). 
philosophizing is a spiritual exercise that foregoes the ideal of total autonomy. But if so, understanding adequately the Buddhist arguments, or Western and Christian arguments with which they are paired, requires that one must be prepared to reconceptualize one's intellectual practice as a spiritual inquiry. And this means that we need to pay attention to our practices even as we attend to theirs, and speak with some candor about what our predicaments are. This richer philosophy of religion becomes in a way actually confessional, a discourse rooted in tradition and even normally understood as arising from and for communities of faith, alongside a similarly intended group of academic colleagues and interlocutors. ${ }^{10}$

To some readers, when I reconceive the philosophy of religion as a spiritual practice with confessional characteristics, I will seem to have traveled too far from what real philosophers of religion think the discipline to be. But I do so because in this way I find myself on surer ground, where I can think better, thinking religiously. Indeed, I have recently ${ }^{11}$ tried out this still more deeply engaged thinking, by taking up the topic of "loving surrender to God" as argued and presented in two classics of spiritual theology, the Treatise on the Love of God by Francis de Sales and the Essence of the Three Mysteries by Vedanta Desika. Both de Sales and Desika, classical theologians, think through carefully the potential and limits of reasoning in spiritual matters, while arguing for continuity between clear-sighted reasoning about self and world on the one hand, and the necessarily interior journey that begins but does not end in reason's hard questions. I found their work attractive because I was interested in pushing still farther the matter of how religious intellectuals write so as to draw their readers into religious activities, such as surrender to God, that stand at the heart of their traditions. Reason and argument have their role, but employing them properly — chastened, literate, aware of their resting point - raises the prospect of actual religious practice. Patil made this point with respect to Ratnakirti's project; my contribution is to argue that I really do intend also an existential event, that a reader might be persuaded actually to surrender to God.

${ }^{10}$ On my understanding of "confessional" as a characteristic of comparative theological discourse, see Hindu God, Christian God, c. 1.

${ }^{11}$ Beyond Compare: St. Francis de Sales and Sri Vedanta Desika on Loving Surrender to God (Georgetown University Press, 2008). 
For now, the relationship among the philosophy of religion, theology, and engaged religious reasoning remains uncomfortable and vexed, but more intimate and intense conversations that violate disciplinary boundaries promise to be so fruitful that no one involved should neglect the opportunity to take the other modes of reasoning seriously. As Patil shows us in splendid detail, the densest and most exact of arguments is still made clearer by catching its religious finality; deeper and engaged religious reflection is never relieved of the need for exact, even detached reasoning; as Kapstein's reflection on Hadot tells us, Buddhist (and other) forms of arguments can rightly be recognized as spiritual exercises. All of this needs to be formalized, of course, but Wood states the balance well in the last paragraph of his essay:

It would be a good thing if more scholars of religion-and especially theologians-read analytic philosophy. Moreover, theologians who want more scholars of religion to read theology ought to agree. So also scholars of religion who want more theologians to read Marxist and Freudian critiques, or wrestle with non-Christian religions, or with social scientific approaches to religion. And for the same reasons, too-there are good arguments there, arguments worth taking seriously, even if one ultimately rejects them. We profit intellectually when we engage with the interdisciplinary other. This is a truism of the religious studies academy, itself inherently interdisciplinary. So too with the analytic other. (959)

Wood should agree that the "ought" runs the other way too. By the obligation of their own commitments to reason, practitioners of analytic philosophy need to take seriously positive, tradition-based theology, including the serious but difficult thinking that occurs in other terms in other religious traditions. None of the disciplines at stake is sufficient without taking the others into account.

I close by reemphasizing that all of this is interreligious. In all such study, reflection proceeds by way of complex learning with respect to multiple dimensions; even more broadly, religious and cultural boundaries are less than absolute because they do not make sense, are not productive, and are in fact crossed repeatedly. In turn, there will be no reason to privilege exclusively any single tradition's manner of reasoning or scriptures or tradition of great teachers. 
We are not just talking about good academic work, nor about a sensitized inclusion of Asian and southern hemisphere thinkers in our philosophical projects. Our disciplines will be intellectually compelling insofar as false boundaries are not imposed. Insofar as truth is at stake, the very content of our disciplines will unsettle conventional divisions between philosophical and religious modes of reflection. 